\title{
MOTIV STRAHA I NJEGOVI MEHANIZMI U HRVATSKOJ FANTASTIČNOJ NOVELI 19. STOLJEĆA
}

Izvorni znanstveni članak Primljeno: 22. 10. 2018 Prihvaćeno: 4. 3. 2019. DOI: $10.15176 /$ vol56no106 UDK 821.163.42"18"

\author{
DOMAGOJ BROZOVIĆ \\ Nezavisni istraživač, Đurđevac
}

\begin{abstract}
Budući da je u svjetskoj književnosti od romantizma nadalje najveći dio fantastične dionice pripovjedne književnosti formiran oko ideje straha od nepoznatoga i neobjašnjivoga, ovaj je prilog usmjeren na manifestacije te emocije u odabranim primjerima hrvatske fantastične novele 19. stoljeća. U raspravi se problematizira i tematsko-žanrovska pripadnost kanonskih novela, i to upravo s obzirom na prisutnost motiva straha. U književnostima zapadnog kruga u 19. se stoljeću pojačano javljaju fantastični pripovjedni žanrovi kojima je motiv straha glavni narativni pokretač, a pojedini elementi fantastički intonirane književnosti s obilježjima književnoga horora prisutni su i u odabranome istraživačkom korpusu: od romantičarskih obilježja Jorgovanićeve fantastike preko premošćivanja realističke poetike i okretanja misticizmu u Gjalskijevoj novelistici do modernističke psihologizacije Matoša i Leskovara. lako se u tradicionalnoj hrvatskoj književnoj historiografiji zadani korpus nije tumačio kroz prizmu motiva straha, njegova prisutnost otvara niz istraživačkih pitanja poput, primjerice, kako se strah manifestira u pripovjednom tekstu, kojoj pripovjednoj razini emocija straha zapravo pripada, kako motiv straha sudjeluje u proizvodnji fantastičnog i irealnog itd.
\end{abstract}

Ključne riječi: fantastika, horor, misticizam, novela, strah, upadajuća fantastika

\section{UVODNA RAZMATRANJA O STRAHU U FANTASTIČNOJ KNJIŽEVNOSTI}

lako znanosti o književnosti u primarnome području interesa nije psihološki fenomen osjećaja, kao ni njihova složenost ni popratne manifestacije, mnogi pristupi književnom djelu ne mogu ih ignorirati, ${ }^{1,2}$ Razlog je taj što u književni (ili, preciznije rečeno, u pripovjedni)

${ }^{1}$ Ova je rasprava prošireni tekst izlaganja održanog na skupu Naracije straha: istraživački uvidi, teorijski problemi i metodološki izazovi 12. i 13. listopada 2017. godine u Institutu za etnologiju i folkloristiku u Zagrebu.

2 Budući da u glavnim operativnim, prije svega genološkim pojmovima ovoga rada postoje složeni prijepori, polemike i višestruka tumačenja, potrebno je prije rasprave barem u kratkim naznakama poku- 
tekst upisane emocije često diktiraju njegovo tematsko određenje. Čak i površan pogled u osnovne tematske sklopove fantastične književnosti svjedoči o tome kako upravo osjećaj straha često dominira tim žanrom. Također, u teorijskim pristupima fantastičnoj književnosti, koji su i u kasnijem, dominantno postmodernističkom okruženju uglavnom ostajali u osnovnim formalističko-genološkim okvirima, raspravljalo se i o simbiozi žanra fantastike i osjećaja straha. Dakako, kada se govori o toj simbiozi na umu treba imati i stupnjevanje realizacije osjećaja straha, tj. razlikovanje straha kao poželjnoga i ciljanoga učinka kojem pojedini pripovjedni tekst dominantno teži te straha kao potencijalne, neobavezne i usputne reakcije u fantastičnom narativu. No najviše je dvojbi bilo oko toga je li fantastika uopće zaseban književni žanr, tj. mogu li se nerealna i iracionalna svojstva pripovjednog teksta smatrati presudnima u konstituciji fantastičnoga žanra ili je, u najširem shvaćanju (i u Jakobsonovoj maniri), fantastika zbog svoje nereferencijalnosti na zbilju zapravo obilježje svakoga književnog teksta (Pavičić 1996: 134-136). Dakako, pritom treba podsjetiti da je tu riječ o naivnom konceptu fantastike koji podrazumijeva banalnu interpretaciju mimesisa kao izravnog referiranja na materijalnu stvarnost, a fantastiku interpretira kao devijaciju u odnosu na tu normu. Međutim, u skladu s konstruktivističkim polazištima, književnost općenito modelira stvarnost, a i zbilja je socijalni konstrukt koji se mijenja sukladno mijenama povijesnih i društvenih okolnosti.

S pojavom ranih gotičkih romana u romantizmu u prvoj polovici 19. stoljeća na književnopovijesnoj razini primjetan je pojačani razvoj intencionalno nemimetičkih narativa u kojima su fantastično i mimetičko isprepleteni do te mjere da se fantastika (iako iracionalna, nerealna i besmislena) nameće kao nova realistička norma. Prema Moorcocku, tradicionalni fantastični motivski kapital otad je podvrgnut individualnim autorskim konceptima i interpretacijama, i to u skladu s pojačanim romantističkim interesom za nepoznato i okultno. Drugim riječima, moderna fantastična djela od gotičkih romana do danas namjerno su fiktivna (Moorcock 2004: 181-185; Mendlesohn i James 2012: 78-79). Po tom ključu fantastičnu fikciju možemo nazvati intencionalnom fantastikom, a realističko-mimetičku fikciju intencionalnim realizmom.

Začetnikom metodoloških pristupa fantastičnoj književnosti vobičajeno se smatra Tzvetan Todorov. Ostavljajući po strani dvojbenosti u Todorovljevoj strogoj izolaciji fantastičnoga žanra, uzrokovane tezom o razlikovanju čudnog i čudesnog, već je on u

\footnotetext{
šati odrediti okvire u kojima se oni u ovome radu koriste. Primjerice, uporaba kategorije žanra u klasifikaciji književnosti toliko je fleksibilna da ulazi i u načelno formalna (npr. ep, roman, novela, drama itd.) i u tematski tipizirana svojstva književnih tekstova (npr. ljubavna pripovijetka, avanturistički roman, fantastična novela itd.). Svjesni ovakve dvostruke geneze pojma žanra i mogućih nepreciznosti, u ovoj raspravi paralelno operiramo s oba njegova značenja, koja na pojedinim mjestima neizbježno kolidiraju. Drugi mogući prijepor tiče se prijedloga razgraničenja kratkih pripovjednih vrsta, prije svega pripovijetke, novele i kratke priče. Načelno, pripovijetka implicira nešto razvijenije događajne lance, zatvorenost kompozicije i stabilni rasplet, ali u bitno manjoj mjeri od romana. S druge strane, počeci kratke priče, njezine fragmentarnosti i fabularne otvorenosti u književnoj historiografiji nastoje se povući sve do romantizma i Edgara Allana Poea. Književna praksa ovu žanrovsku načelnost ozbiljno dovodi u pitanje, čak i u konkretnim primjerima navedenim u ovoj raspravi jer se u njima mogu naći karakteristike i pripovijetke i kratke priče. U tome se smislu u ovom radu radi izbjegavanja nesporazuma koristi pojam novele, i to u najširem i neutralnom značenju - kratkog proznog djela.
} 
svom pionirskom Uvodu u fantastičnu književnost iz 1970. godine artikulirao tezu prema kojoj fantastično kod čitatelja izaziva posebno djelovanje, često strah, užas ili jednostavno radoznalost ili neki drugi oblik uznemirujućeg čuđenja (Todorov 1987: 51-52). Upravo taj recepcijski impuls kolebanja u čitatelju, na koji se Todorov često poziva, ima indirektnu mogućnost izazivanja straha koja je, prema njegovoj argumentaciji, zapravo obilježje književnoga teksta koje čitatelj treba prepoznati.

U počecima domaćih promišljanja o fantastičnoj književnosti Branimir Donat kategoriji straha, slično kao i Todorov, pridaje fundamentalnu ulogu u formiranju ideje začudnoga u fantastičnoj književnosti, no ne ograničava je isključivo na kategoriju teksta i, posljedično, čitatelja. Za razliku od Todorova, Donat u svojoj duljoj biobibliografskoj studiji koja prethodi poznatoj Antologiji hrvatske fantastične proze i slikarstva iz 1975. godine povezanost fantazijskih motiva i osjećaja straha provlači kroz egzistencijalistički intonirano, prvenstveno autorsko, a potom i čitateljsko prepoznavanje fantastičnog kao poligona za prevladavanje osnovnih ljudskih strahova. U tom je smislu fantastična umjetnost, prema Donatu, najautentičniji izraz slobode izmišljanja (Donat 1975: 10), a iz te se teze može implicitno zaključiti kako osjećaj straha pripada zapravo svim članovima recepcijskog trokuta podjednako književnom tekstu, autoru i čitatelju.

U najširem shvaćanju i uz pretpostavku da je promatramo kao specifičan žanr, fantastična književnost uključuje prilično širok dijapazon tematski definiranih podžanrova, kao što su npr. gotski roman, priče o duhovima, horor, znanstvena fantastika, visoka ili epska fantastika itd. Još su ruski formalisti pokazali kako kategorije književne forme i žanrovskih konvencija nisu izolirane i stabilne, nego su promjenjive i ovisne o nizu ne samo estetskih nego i izvanknjiževnih čimbenika (društvenih, političkih, povijesnih). U tom smislu, U većini fantastičnih narativa u zapadnoeuropskoj književnosti 19. stoljeća (npr. u romanu Frankenstein M. Shelley, u novelama E. A. Poea, M. R. Jamesa i G. de Maupassanta ili u Draculi B. Stokera itd.) uočljiv je velik broj tematskih i pripovjednih svojstava koja su mahom zajednička pobrojanim fantastičnim podžanrovima. Što se društveno-političkih odraza u zadanim djelima tiče, većina književnih povjesničara indikativnim smatra "duh vremena" 19. stoljeća, obilježen industrijskom revolucijom i pojavom novih tehnologija (npr. u romanima Frankenstein Mary Shelley i Čudnovat slučaj dr. Jekylla i g. Hydea R. L. Stevensona), postupnim gašenjem prosvjetiteljske filozofije i gubitkom vjere u razum (npr. u pripovijetkama E. A Poea), posljedičnim pojačanim interesom za okultno i simbolističko (npr. u novelama M. R. Jamesa ili G. de Maupassanta), pa čak i propašću te svojevrsnom demonizacijom plemstva (u romanu Dracula Brama Stokera). U svim navedenim primjerima fantastika ima konkretno uporište u izvanknjiževnoj stvarnosti, a realizira se upravo kroz emociju straha. Fantastičnom fikcionalizacijom čitateljske empirije i društveno-političkih realija otvara se motivacijski prostor za izazivanje jedne konkretne emocije - straha.

Indikativno je kako u svojoj Teoriji književnosti Rene Wellek i Austin Warren (1949) izdvajaju upravo gotski roman kao podvrstu fantastičnog pripovijedanja na čijem primjeru demonstriraju tri zajedničke karakteristike svih proznih djela: prepoznatljivu tematiku, 
skup stalnih motiva i Kunstwollen, tj. estetsku namjeru koja povezuje tematiku i motiviku. Uz prepoznatljivu tematiku gotskih romana, za taj su podžanr karakteristični i specifični pripovjedni, opisni i ostali pomoćni motivi (npr. ruševni dvorci, tajni prolazi u njima, groblja, samotne šume, otmice, potjere itd.), a znakovitost estetske namjere gotskoga romana sadržana je u tome "da se pruži posebna vrsta prijatnog užasa i uzbuđenja" (Wellek i Warren 1949: 242-243). Pod pojmom estetske namjere, kako ga Wellek i Warren na tragu njemačke teorije na prijelazu stoljeća poimaju, ne misli se na konkretne autorske, ili čak ideološke intencije, već na estetski princip koji objedinjuje književne postupke i čimbenike zadanoga djela, uključujući izbor motiva i tema. ${ }^{3}$ Ako o tome učinku (koji je, čini se, najvažnija karakteristika) govorimo u mjerilima klasične aristotelijanske poetike, vrijedi istaknuti tezu prema kojoj uspješan fantastični narativ (posebice gotski roman ili horor kao njegove podvrste) zapravo probija granice Aristotelovog koncepta katarze. Drugim riječima, estetska namjera pružanja prijatnog užasa u čitatelju mora ostati manifestirana čak i nakon čitanja književnoga djela. ${ }^{4}$

S obzirom na netom navedene osnovne smjernice u proučavanju uloge motiva straha u fantastičnoj književnosti, u nastavku ovoga priloga o tome će se suodnosu raspravljati na antologijskim primjerima hrvatske devetnaestostoljetne novele kojima se u književnoj historiografiji ujedno pripisuju sâmi počeci novije hrvatske fantastične proze: ${ }^{5}$ Ljubav na odru i Stella Raïva Rikarda Jorgovanića, odabrane priče K. Š. Gjalskog i A. G. Matoša te Misao na vječnost Janka Leskovara. Također je potrebno napomenuti da 19. stoljeće ovdje ne shvaćam strogo proceduralno, već prihvaćam klasičnu periodizacijsku argumentaciju o tzv. dugom 19. stoljeću koje po svojim poetsko-estetskim, ali i društveno-političkim karakteristikama de facto završava s krajem hrvatske moderne i modernističkog pokreta 1914. godine.

\footnotetext{
${ }^{3}$ Teorijsko utemeljenje pojma Kunstwollen, kako ga tumače Wellek i Warren, s osobitom pozornošću na emociju straha i njezine manifestacije prihvaća i Ognjanović u svojoj ekstenzivnoj studiji o angloameričkoj horor književnosti (usp. Ognjanović 2014: 22-24).

${ }^{4}$ Ideja o antikatarzičnim svojstvima (književnog i filmskog) horora nosiva je teza studije The Philosophy of Horror Noëla Carrola (usp. Carrol 2004: 7-9, 18, 93-95, 180, 246). Predloženom terminu antikatarze nije cilj negacija Aristotelova koncepta katarze, koji svakako uključuje emocionalnu dimenziju učinka djela na čitatelja. Međutim, prema Carrolu, taj je učinak uglavnom bitno ograničen, tj. nije u prirodi svakoga žanra da se u reakcijama publike vjerno reproduciraju emocionalna stanja protagonista. Carrolovim riječima, Othello je ljubomoran, ali recipijent nedugo po završetku čitanja ili gledanja to više nije. Horor probija granicu katarze sve do učinka zrcaljenja osjećaja i izoliranja tog efekta, tj. do primjetno većeg stupnja identifikacije s emocionalnim stanjem protagonista negoli u ostalim žanrovima. Glavni lik i čitatelj zajedno strahuju od sâmoga uzroka straha, a čest je učinak horora da se takav emocionalni odgovor zadrži relativno dugo nakon čitanja ili gledanja, tj. dolazi do primjetnog odgađanja katarze.

${ }^{5}$ Detaljnije o periodizacijskim razgraničenjima u hrvatskoj fantastičnoj književnosti usp. Kuvač-Levačić (2013: 23-33).
} 


\section{RIKARD JORGOVANIĆ: LJUBAV NA ODRU I STELLA RAÏVA}

lako su se u hrvatskoj književnosti fantastični motivi sporadično javljali i u prijašnjim razdobljima, i to ponajprije $u$ alegorijskom ključu, početak pravog kontinuiteta hrvatske fantastične književnosti tradicionalno se pripisuje Rikardu Jorgovaniću (Donat 1975: 29-30; Nemec 1994: 8-9; Pogačnik 1999: 337-338). Premda Šenoin suvremenik, Jorgovanić je ono što je Barac nazvao uzmakom natrag (Barac 1952: 55) - on je romantički epigon čija proza dominantno zadržava karakteristike predšenoinskog, donekle trivijaliziranog novelističkog korpusa (Šicel 1991: 36-37, 44-45). Također, iako se Jorgovanićev književni opus proučavao isključivo u sprezi sa Šenoinim, književni su povjesničari prepoznali prisutnost novih, neobičnih motiva koji su ipak prilično neujednačeno vrednovani. Barac ih je po uzoru na Šenou nazvao "živom fantazijom", Šicel uočava važnost motiva sna i hipnagogičkih stanja, ali ih pripisuje predmodernističkim psihologijskim nastojanjima, tek ih Donat argumentirano terminološki određuje kao nedvojbeno fantastične, a Frangeš indikativno ističe upravo stravičnost kao dominantnu karakteristiku Jorgovanićeve proze. ${ }^{6}$

Ako uzmemo u obzir to da su fantastični motivi u Jorgovanićevoj prozi najviše eksponirani u novelama Ljubav na odru iz 1876. i Stella Raïva iz 1880. godine, da je u tim istim novelama prepoznatljiv utjecaj romantičara, ponajviše Edgara Allana Poea (koji je u trenutku objave Ljubavi na odru već dvadeset sedam godina mrtav, no njegov pjesnički, prozni i teorijsko-esejski opus Jorgovaniću su dobro poznati (Peričić 1999: 320, 325)) te da su hrvatski preporoditelji kao Poeovi suvremenici u odnosu na zapadnoeuropski romantizam bili preokupirani uglavnom nacionalno-identifikacijskim, a ne fantastičnim i egzotičnim temama, postaje nam razumljivija relativno kasna pojava fantastike u hrvatskoj književnosti. Međutim, Jorgovanić u svojim epigonskim romantičarskim pokušajima fantastiku koristi vjerno, u skladu s glavnim odrednicama tih poetika.

Upravo u spomenutoj Poeovoj teoriji novele (obrazložene u njegovom prikazu zbirke novela Dva puta ispričane priče Nathaniela Hawthornea) ističu se formalne prednosti kratkih proznih žanrova u odnosu na roman - novela se, prema Poeu, čita kontinuirano, precizne je strukture, a siže joj je usmjeren k čistom i jednostavnom efektu. Zbog svih navedenih razloga upravo su kratki pripovjedni žanrovi najpogodniji za fantastično-jezoviti učinak (Ognjanović 2014: 163-165). Čini se da je svijest o noveli kao o žanru u kojem postoji visok stupanj mogućnosti realizacije fantastičnog, neobjašnjivog ili tajnovitog u razdoblju romantizma zapravo nepisano pravilo jer romantičarska novela pokazuje posebnu sličnost i s umjetničkom bajkom te s ostalim fantastičnim žanrovima, gurajući je u prostor tajnovitog, mističnog i okultnog, po prešutnim propozicijama pripadajuće književne epohe (Bobinac 2012: 214).

Dakako, kada govorimo o fantastici u kontekstu romantizma, u obzir treba uzeti Schlegelove teze o beskonačnosti iz njegova Razgovora o poeziji nastale u okviru njegova

${ }^{6}$ Rekonstrukcija paradigme kritičke recepcije Jorgovanićeva književnog djela preuzeta je od Pogačnik (1999: 338-339). 
koncepta "progresivne univerzalne poezije", a u kojem se mitologija (de facto manifestacija fantastičnog) izdvaja kao modus kroz koji se najlakše može približiti beskonačnome (tj. vječnoj ljubavi i svetoj ispunjenosti) (Bobinac 2012: 171). S obzirom na spomenuti pojam estetske namjere koji su iz njemačke teorije preuzeli Wellek i Warren, "prijatni užas" u romantičarskoj fantastici usmjeren je na tu istu težnju prema beskonačnosti (štoviše, na ljudsku spoznajnu imperfekciju, na nemogućnost znanja o beskonačnosti, pa i na mogućnost teškog razočaranja). Upravo je motiv smrti, koji objedinjuje mogućnost prolaska kroz portal prema apsolutu i fantastičnosti, ali i nemogućnost povratka, taj na kome se prelamaju imenovane silnice i ne treba čuditi to što ga romantičarska fantastična novela često koristi.

U Jorgovanićevoj noveli Ljubav na odru morbidna opčinjenost tugom i tamom jasno je označena već u sâmome naslovu te izravno asocira na Poeov motiv mrtve drage, koji se u različitim inačicama i motivskim nijansama često pojavljuje u njegovom pripovjednom korpusu (npr. Berenice, Ligeia, Eleonora, Pad kuće Usher, Ovalni portret itd.). Vasilije Hvostov, glavni junak Ljubavi na odru, zadržava sve karakteristike tzv. suvišnoga čovjeka kao svojevrsne najave modernističkih dekadenata, a pripovjednu pretpovijest takvoga stanja treba tražiti upravo u motivu mrtve drage. Na sadržajnoj razini Hvostovljeva opčinjenost djevojkom Anđelinom, koju je vidio kako pjeva u jednoj ruskoj krčmi u Rimu, utemeljena je na nostalgičnim prisjećanjima na staru, davno preminulu ljubav Adelaide i na njegovoj staroj želji da kao slikar ovjekovječi na platnu njezin mrtvački odar. Nakon godina pokušaja i promašaja slučajno nailazi na Anđelinu, koja izgledom podsjeća na Adelaide i može poslužiti kao slikarski model.

U motivu mrtve drage objedinjavanjem metafizičkog podteksta smrti i erotike estetska namjera učinka straha dodatno je pojačana emotivno-psihološkim angažmanom likova. Na tragu romantičarske poetike, muški akter i draga nisu razdvojeni subjekti, već efektivno čine jedan jedinstveni dualitet, a nestajanjem jedne polovice pojačavaju se negativne emocionalne posljedice za onoga tko ostaje. U duhu romantičarske poetike i sâm Poe je u svom autoprogramatskom eseju Filozofija kompozicije istaknuo kako je smrt lijepe žene najpoetskija tema na svijetu (Grgić 2016: 70; Ognjanović 2014: 177). Također, uzimajući u obzir to da se na ovaj način mogućnost prekogrobnog postojanja voljene žene otvoreno uspoređuje s pjesničkim stvaranjem kao još jednim oblikom prevladavanja fizičkog života i schlegelovskog načina dostizanja beskonačnosti, suvremeni teoretičari poput, primjerice, Elizabeth Bronfen u problemu racionalne nespoznatljivosti smrti, ljubavi i umjetnosti u postmodernističkoj maniri prepoznaju granice referencijalnosti jezika i srodnih prikazivačkih sustava te time cjelokupnoj problematici dodaju i dimenziju autoreferencijalnosti (Grgić 2016: 59, 65, 67).

U sceni Anđelinina prvoga poziranja izrazito je naglašen bizarni ambijent prostorije s lažnim odrom, presvučenim crnim baršunom i okruženim svijećnjacima s voštanicama, a još više reakcija djevojke koja je problijedjela kao smrt i umalo se onesvijestila. Ta je scena indikativna iz više razloga: iako impulsi za osjećaje misterija i strave dolaze iz nepo- 
sredne realistički intonirane okoline (tj. iz naglašene mrtvačke atmosfere koja intenzivno naznačuje sâmu mogućnost umiranja kao potencijalnog portala u nepoznati svijet), ta je ista racionalna stvarnost ustvari podređena subjektivnoj percepciji djevojke. Naglašen je njezin psihološko-emocionalni doživljaj te situacije, kao i njezine tjelesne manifestacije toga doživljaja. Emocija straha u tipičnom romantičarskom gotiku više nema veze s prosvjetiteljskim objektivnim i distanciranim diktatom razuma, a učinak književnoga teksta u proizvodnji "ugodne strave" tim je jači ako se postigne premošćivanje Aristotelove katarze i prelazak tih emocija na čitatelja, o čemu je bila riječ u uvodu. U finalu Ljubavi na odru ta je potencija strave dodatno naglašena kada Anđelina nesebično počinja samoubojstvo kako bi Hvostovu pružila savršen model, i u tih nekoliko rečenica on postaje katalizator tih osjećaja.

I dalje pod uočljivim motivskim utjecajem E. A. Poea, ta je fantastična dimenzija doticaja sa smrću posebice naglašena u još bizarnijim scenama Jorgovanićeve novele Stella Raïva. $\mathrm{Na}$ sadržajnoj razini, indijska operna pjevačica iz naslova novele prepričava ravnatelju orkestra (inače okvirnom pripovjedaču u prvom licu) priču o svojoj ljubavi s Emericom Horvatom, siromašnim studentom podrijetlom iz Hrvatske tijekom studentskih dana u Milanu, i njegovoj nesretnoj smrti. Višestrukim ulančavanjem naratora i prepuštanjem prava na priču drugoj osobi ostvaruje se dojam nepouzdanosti pripovjedača i poroznosti same strukture. Impuls Stellina pripovijedanja Emericova je lubanja, koja simbolički, bizarno i morbidno presijeca do te točke realistički intonirani diskurs novele. Tako se, osim poovske mrtve drage (u ovom slučaju mrtvog dragog), u strukturu novele nasilno uvodi dimenzija slučajnog otkrića bizarne perverznosti, a priča služi kao mehanizam njezinoga opravdanja, gotovo istovjetno kao u Poeovu Crnom mačku? Ravnateljev je strah pojačan i dodatnim iščekivanjem priče jer Stella odgađa priču sve do ponoći. I u ovome slučaju snažni impulsi straha dolaze iz zapravo realistički intoniranog konteksta, a strah je proizvod emocionalno-psihološkog doživljaja tog konteksta. Međutim, konačno opravdanje ni ovdje ne slijedi racionalno-prosvjetiteljsku logiku, nego, dapače, pojačava osjećaje straha i nemira zbog kratkog metafizičkog pogleda na drugu stranu koji je u finalu novele de facto iznevjeren - detaljna scena ekshumacije sa škripanjem lijesa koje je uspoređeno sa škrgutanjem mrtvačkih zubi, raspadnuto tijelo koje već nemilice konzumiraju crvi i hladnokrvna dekapitacija mrtve ljubavi vjerojatno su najbolji primjer hrvatskog književnog horora. Željeni učinak u smislu čitateljskih reakcija najbolje opisuje zadnja rečenica novele koju izgovara ravnateljevo prvo pripovjedačko lice: "Te se noći nisam usudio noćiti sâm kod kuće" (PSHK 44 1970: 486).

7 U svojoj Poetici horora Ognjanović uočava četiri tematska ciklusa u Poeovoj novelistici: mrtva draga, "Đavo perverznosti" (tj. nekontrolirani poriv za bezrazložnim zločinom), iracionalno motivirana osveta te kozmička strava (tj. čovjekova spoznajna ograničenost da pojmi misterij vlastitog postojanja u kozmičkim razmjerima) (usp. Ognjanović 2014: 175-176). Hrvatska fantastična novelistika 19. stoljeća na tematskoj razini najviše je participirala upravo u motivu mrtve drage, no Poeov utjecaj primjetan je i u rubnoj prisutnosti ostalih njegovih tematskih preokupacija.

${ }^{8}$ Kratica za ediciju Pet stoljeća hrvatske književnosti. 


\section{TAJINSTVENE PRIČE KSAVERA ŠANDORA GJALSKOG}

U paradigmi hrvatske književnosti 19. stoljeća prva zapaženija premreženost fantastičnih motiva i induciranja čitateljskoga straha, dakako uz još uvijek jasan utjecaj Poeove novelistike, prepoznatljivi su nakon Jorgovanića u kratkim mističnim narativima K. Š. Gjalskog. lako tradicionalna književna historiografija uvjetno potvrđuje pripadnost njegova književnoga opusa razdoblju realizma, većina hrvatskih realista radi neku vrstu otklona od ideala neutralnosti, neangažiranosti i objektivnosti u pripovijedanju, koji se u Gjalskijevu slučaju pod utjecajem Turgenjevljeve dezintegracije realizma manifestira u lirsko-romantičarskim opisima interijera i eksterijera te snažnom nostalgičnom portretiranju vrlo česte realističke teme moralnoga i materijalnoga propadanja plemstva, personificiranog u liku zagorskoga aristokrata Batorića u zbirci Pod starimi krovovi iz 1886. godine. Osebujan status u Gjalskijevu opusu ima kraća novelistička zbirka Tajinstvene priče iz 1913. godine, koja uz još nekoliko pripovijetki čini važan impuls hrvatskoj fantastičnoj književnosti i snažnu kariku između Jorgovanićeva romantizma i Matoševe paradigmatske fantastične proze (Pogačnik 2000: 84-85), a Gjalskijev pripovjedački stil i ideološko-odgojne pretpostavke glavnih likova bitno su transformirali pristup fantastičnim motivima i motivu straha u odnosu na Jorgovanića. ${ }^{9}$ Također, mada konkretni književnopovijesni dokazi o Gjalskijevu izravnom tekstualnom kontaktu s Poeom ne postoje, zbog snažne prisutnosti ranije spomenutih motiva, pretpostavlja se da je Gjalski Poea čitao u Baudelaireovu prijevodu na francuski (Stojanović 1983: 442). Ako se zadržimo na drugim mogućim komparatističkim poveznicama, mistična zanesenost životom poslije smrti uz simbolistička obilježja fatuma ili sudbine uz nezaobilazno transponiranje osjećaja straha s književnih likova na čitatelja standardni su narativni mehanizmi u klasičnim pričama o duhovima s prijelaza stoljeća koje su nastajale gotovo istovremeno kad i Gjalskijevi prinosi hrvatskoj fantastičnoj književnosti, ali ih on najvjerojatnije nije poznavao. Međutim, visok stupanj sličnosti među njima verificira "duh vremena", tj. orijentiranost prema misticizmu i okultizmu u fantastičnoj prozi na razmeđu realizma i esteticizma. Konkretno, ovdje se misli na paralele Tajinstvenih priča s, primjerice, novelom Okretaj zavrtnja Henryja Jamesa iz 1898. ili sa znamenitim pričama o duhovima Montaguea Rhodesa Jamesa, nastajale tijekom 1910-ih godina. Naime, i Gjalskijevi protagonisti i protagonisti dvaju prezimenjaka Jamesa suočeni su s duhovima kao okultnim manifestacijama "života poslije smrti", i to mimo vlastite volje, pri čemu je veći pripovjedni naglasak na subjektivnom doživljaju natprirodnog susreta negoli na pripovjednoj događajnosti.

U užoj analizi novelističke građe, dok Jorgovanićevi likovi poput Hvostova rezoniraju u izvanlogičnoj sferi, mistični su i neurotični romantičarski zanesenjaci i samim tim sličniji Poeovim karakterima, Gjalskijev Lucio Ranjić iz Notturna, doktor Mišić te Vladimir Slavetić

\footnotetext{
${ }^{9} \mathrm{U}$ ovoj analizi ostajemo u okvirima Tajinstvenih priča, koje zapravo grupiraju tri novele koje su objavljene dosta ranije. Redoslijedom iz sâme zbirke, to su Notturno (1893), San doktora Mišića (1890) i Kobne slutnje (1894). U literaturi se kao novele s mističnim i fantastičnim sadržajima spominju još i Mors (1890), Ljubav lajtnanta Milića (1915) i Sasma neobični i čudnovati doživljaji illustrissimusa Šišmanovića (1927).
} 
iz Kobnih slutnji skloniji su racionalizaciji neposrednih fenomena, kako realističnih tako i fantastičnih (Detoni-Dujmić 1982: 80-82). Proizvodnja motiva straha u svakom od tih slučajeva počinje od eksplicitnih faustovskih dvojbi i prihvaćanja kantovskih teza o nesavršenosti osjetilne spoznaje te mistične mogućnosti i vjere u postojanje nečega nedefiniranoga iza empirije. Taj je mehanizam vidljiv u Gjalskijevoj antonimičnosti opisa duševnih stanja glavnih likova te opisa prostora. Naime, kod Jorgovanića je uočljiva poeovska crta paralelizma jednog i drugog - jeziva atmosfera zatvorenog prostora "ukrašenog" odrom ili lubanjom kao katalizatorom posredovanja primarnog i sekundarnog svijeta u potpunosti odgovara spomenutom "divnom užasu” koji se s likova prenosi na čitatelje. U Gjalskijevu slučaju kurije Hrvatskoga zagorja nisu mrtav pejzaž i propadajući dvorci koji šire mistični užas u tipičnoj Poeovoj maniri, nego Gjalskijevi otvoreni i zatvoreni prostori i dalje prate logiku turgenjevljevskog poetskog realizma iz zbirke Pod starimi krovovi. Prostori Hrvatskoga zagorja u Tajinstvenim pričama nisu prostori strave i užasa, nego su u uobičajenom kontekstu Gjalskijeve proze zapravo idealizirani prostori s gustim nacionalnim, povijesnim i običajnim presjecima (Detoni-Dujmić 1982: 80-82; Lőkös 2010: 291-293).

Model po kojem se motiv straha uvodi djelomično odgovara kategoriji upadajuće fantastike (engl. intrusion fantasy) koju je predložila britanska povjesničarka književnosti Farah Mendlesohn. Kako joj i ime kaže, fantastični elementi u upadajućoj fantastici upadaju u realistički intoniran svijet remeteći ga i uvodeći u njega uzročno-posljedični kaos. Glavni likovi, kognitivno nenaviknuti na fantastične elemente, osjećaju začudnost, divljenje, a često upravo i strah te se služe svojim, još prije početka pripovjednog vremena stečenim iskustvima kako bi izbacili fantastično iz primarnoga svijeta (Mendlesohn 2008: xxii-xxiii). U misticizmu Tajinstvenih priča zamjetan je otklon od navedene težnje za izbacivanjem fantastičnog, opredmećen u upadajućem elementu tajanstvene prikaze tipične poeovske mrtve drage koja svojim učestalim pojavljivanjima predeterminira neki kobni događaj u budućnosti.

Primjerice, u Notturnu se pripovijeda o opetovanim susretima glavnog protagonista Lucija Ranjića s prikazom njegove preminule drage, Jelene. Motiv straha izuzetno je jak u onim trenucima kada se pojavljuje tajanstveni duh, zorno prikazujući spomenutu faustovsku sumnju u vlastiti racionalizam te posljedičnu strepnju od mogućnosti prelaska kroz portal smrti. Uzevši u obzir spomenutu tezu o romantičarskom dualnom jedinstvu lirskoga subjekta i drage, mogućnost ponovnog sjedinjavanja u sadržajnoj strukturi Notturna najavljuje rasplet novele i kobno Ranjićevo samoubojstvo. Jasan otisak Schopenhauerove filozofije voluntarizma, kao česta eksplicitna ideja, naglašen je u motivu "oživljene" mrtve drage koja se pojavljuje upravo zahvaljujući nadindividualnoj volji sâmoga junaka, koja prožima sve ovostrane i onostrane oblike postojanja te nastavlja postojati kao junakova utjelovljena predodžba (Grgić 2016: 64).

Motiv mrtve drage s ekstenzivnim varijacijama na tu temu posebice je označen u noveli San doktora Mišića, u kojoj naslovni glavni lik, također odgojno ukorijenjen u racionalizam, biološke znanosti i fiziologiju, u čestim bizarnim snovima viđa lik prekrasne mlade djevojke 
koja mu se u raznim inačicama pokazuje kao umrla. Bitno je ovdje također naznačiti ulogu fizičkog prostora te novele, tj. dvorca Jabučevačkog, čiji je interijer već od prve rečenice obilježen kao prostor presijecanja ovostranog i onostranog u vidu opsjednutosti duhovima. Poetička realističnost tipične zagorske kurije postupno se degradira kroz motive predeterminacije, snova i nenadane melankolije glavnog lika. Česta Gjalskijeva narativna premisa stanovite polemike pozitivizma znanosti s jedne strane te nedokučivosti mistično-okultnog prostora s druge strane izražena je u izravnom Mišićevu tumačenju nadolazećih snova kao čistih fizioloških produkata loše probave, no zato je Batorićevo tumačenje u uvodnim sekvencama novele naznaka kobne slutnje te se s takvom karakteristikom pokazuje kao vrlo važan sadržajni i kompozicijski element. Upravo je Batorićeva interpretacija indikator promjene tumačenja s racionalno-fiziološkog na okultno-mistično jer je Batorić glavni lik većine novela iz zbirke Pod starimi krovovi, koja se u književnopovijesnim pregledima označava kao primarno realistička, no također treba uzeti u obzir da se mistično-okultnoj argumentaciji pojedinih događaja Batorić priklanja i u toj novelističkoj zbirci (Lőkös 2010: 291). Određeni se dijelovi teksta mogu interpretirati i kao autorovo polemiziranje sa Schopenhauerovim tumačenjem snova, ukazanja i proricanja prema kojemu su te pojave samo fiziološke manifestacije proširenja mogućnosti ljudske spoznaje (Grgić 2016: 65). Gjalski u poeovsko-jamesovskoj maniri ipak inzistira na njihovoj tajanstvenosti i neobjašnjivosti.

Jezivost somnabulističkih interferencija kroz tu se novelu gradacijski povećava, a najjača je upravo u trenucima osebujne izmjene hipnotičke i zanosne erotike (koja u potpunosti ide u prilog spomenutom romantičarskom jedinstvenom dualitetu lirskog, tj. pripovjednog subjekta i izabrane ljubavi) te motiva smrti i njezine brutalne jednostavnosti, koji se sudaraju, primjerice, u prikazu lijepog golog ženskog tijela na obdukcijskom stolu i Mišiću jezive i neprihvatljive mogućnosti materijalnog skrnavljenja toga tijela ili pak ledenih poljubaca mrtve djevojke u snovima koji su Mišiću istovremeno i privlačni i zazorni. Drugim riječima, strah u Snu doktora Mišića generiran je u sâmom književnom liku, a nastaje kao posljedica specifične transformacije motiva mrtve drage koja sada simbolizira rascijepljenost između empirijskog pozitivizma i romantičarske zanesenosti. U ključnim trenucima koji su gradativno dovodili do klimaksa osjećaja straha, glavni se lik redovito probudi i simbolički vraća u vlastitu realistički intoniranu stvarnost, ali po propozicijama fantastičnih i horor žanrova nosi spomenute antikatarzične naznake ljubavi i straha natrag u primarni svijet, fizički vidljivo manifestira psihofizičke posljedice tjeskobe te u konačnici gubi vlastiti racionalno-materijalističko-pozitivistički mir.

Također, zbog poetske gustoće opisa napetost između istovremene privlačnosti i zazornosti mrtve drage jača je negoli u Jorgovanićevoj prozi, odnosno u spomenutom prijatnom čitateljskom užasu koji se nudi u teorijskoj mogućnosti prelaska kroz samrtni portal. Ta je poanta dodatno zaoštrena u sâmom raspletu novele, u kojem je doktor Mišić pozvan na liječnički uvid ubijene ciganske djevojke u krčmi u obližnjem selu, a na obdukcijskom stolu na realističkom planu, tj. u primarnom svijetu jave nađe mu se ista ta djevojka iz snova. Nakon što se pri obdukciji porezao te tako otrovao mrtvačkom krvlju, snovi se verificiraju kao vjerodostojni nositelji kobnih slutnji doktora Mišića o vlastitoj smrti. Izrazita 
logička povezanost i kardinalni primjer funkcionalne motivacije u ovoj sceni ukazuju na to da u Gjalskoga strah nije nasumična i kaotična kategorija, nego je vođen sustavno smišljenom pripovjednom logikom usmjerenom prema sasvim određenom cilju. Opisani motiv neizbježnosti zadane sudbine i pripadajućega straha snažan je motivator i u Kobnim slutnjama, gdje na sadržajnoj razini, doduše, više nema motiva mrtve drage, pa ni toliko jakog utemeljenja u somnabulizmu, nego kao katalizator kobnih događaja služi antikni model ljudskog kostura od slonovače, koji se također može interpretirati kao predmet premrežene strasti, ljubavi te ambicioznosti i istovremene zazornosti od toga predmeta kroz koji se manifestira opipljiv strah od smrti i predeterminiranost sudbine. Naime, u želji da pribavi kostur za svoju zbirku antikviteta glavni lik Vladimir Slavetić izaziva mistične kobne slutnje vlastite majke da će umrijeti ako u životu bude imalo slobodniji od njezina utjecaja te potajno putuje po željeni predmet židovskom antikvaru u Veneciju.

\section{FANTASTIKA U MODERNISTIČKOJ NOVELI}

Godine 1892. Antun Gustav Matoš objavio je pripovijetku Moć savjesti, a Janko Leskovar Misao na vječnost te time iniciraju novi poetski senzibilitet koji se odmiče od realističkog mimetizma, koji je utemeljen na individualnim aspektima ljudske psihe i mjestimice se približava fantastičkom strukturiranju sižea. Antun Gustav Matoš napisao je šezdesetak novela, otprilike polovica grupirana je u tri klasične zbirke, Iverje iz 1899., Novo iverje iz 1900. te Umorne priče iz 1909. godine, dok je ostatak raštrkan po periodici. U žanrovskoj i stilskoj gustoći te priličnoj neodređenosti Matoševe modernističke novelistike primjetan je krug pripovijedaka s tipičnim simbolističkim obilježjima kao što su, primjerice, spomenuta Moć savjesti, također i Camao, Miš ili Iglasto čeljade. ${ }^{10}$ Tradicionalna književna historiografija prihvaća zaključak o napuštanju realističke pozadine u tim novelama te prepoznaje formaciju umjetničkoga miljea kao onu koja je psihički rastrojenim identitetima važnija za izgradnju vlastite ličnosti, pri čemu često ističe i prisutnost fantastičnih i grotesknih motiva. ${ }^{11}$ Slijedeći tu logiku, posve neuobičajeno u prezentaciji dimenzije straha dolazi do osebujnog obrtanja odnosa na relaciji ovostrano - onostrano, pa se u Matoševu slučaju ne može govoriti o klasičnom tipu fantastike. Dapače, glavni likovi kao da su potpuno nesvjesni prisutnosti motiva koji iz korijena preuređuju uobičajene kauzalne odnose, a veća

\footnotetext{
${ }^{10}$ Dubravka Oraić Tolić, primjerice, u svojoj studiji Čitanja Matoša predlaže klasifikaciju u kojoj se eksplicitno kao kriterij razdiobe uvodi odnos između primarnog i sekundarnog svijeta. Dok se u impresionističkim novelama inzistira na psihološkoj motivaciji i visokom stupnju individualne percepcije realističko-mimetičkih motiva, Matoševe simbolističke novele participiraju na podjednakom supostojanju realnog i irealnog svijeta. Osim psihološkom motivacijom, to se postiže i uvođenjem fantastičkih motiva i srodnim postupcima očuđenja (usp. Oraić Tolić 2013: 39-41, 54-56, 229-237).

${ }^{11}$ Uz dosadašnje usputne indicije prisutnosti fantastičnih motiva tek recentna studija Književno njihalo Bernarde Katušić Matoševe novele i sklonost simbolističkom ustroju interpretira kao modernističke preinake bajkovne strukture (Katušić 2017: 181-221). Ovaj vrijedan doprinos, doduše, ne ističe posebno motiv straha u Matoševoj novelistici, vjerojatno zbog toga što je u njoj ta emocija uglavnom neobavezna nuspojava, a ne nužno i dominantni učinak, o čemu je bila riječ i u uvodu.
} 
narativna koncentracija usmjerena je zapravo na izvanjske posljedice njihovoga vlastitog društvenog autsajderstva i psihološke dekadencije.

Matoševe simbolističke novele često su vrlo neobičnih i zazornih sadržaja koji završavaju tragično, a u gradnji sižea uočava se pravilan uzorak. Primjerice, Josu Cicvarića u Moći savjesti u snu progone štapovi, u noveli U čudnim gostima protagonist u bijegu pred policijom zaluta u tipični gotički dvorac gdje ga nakazni kineski sluga priređuje za klanje svom gospodaru, degeneriranom plemiću. U pripovijetki Miš student Milinović nečiste prošlosti i sâm postaje žrtva neobične zamke za životinjicu koja ga noću podsjeća na vlastitu nečistu savjest i samoubojstvo njegove trudne djevojke. Novela Iglasto čeljade pripovijeda o čovjeku koji se ubio pritišćući iglu sa šešira svoje drage na vlastite grudi, a u noveli Camao pijanist Alfred Kamenski i njegova ljubavnica Fanny žrtve su krvavog koljačkog pohoda njezina ljubomornog muža.

U igri dualizma između realnosti i bizarnosti, glavni likovi žive u svijetu u kojem ne vrijede vobičajene logičke uzročno-posljedične veze kao u Gjalskoga, nego po tipičnim modernističkim tehnikama individualizacije i psihologizacije bježe od zbilje u svijet subjektivnosti i mašte te ga u potpunosti prihvaćaju. U toj je prozi osjetan i blagotvoran utjecaj Egdara Allana Poea, čak i u onim novelama koje u središtu nemaju bizarni događaj. Poznata je, recimo, schlegelovska romantična apsolutna idealizacija nepoznatih žena koje protagonisti slučajno susreću u klasičnim novelama Balkon i Cvijet sa raskršća te njihovo tipično modernističko premještanje u umjetničku sferu nedokučivosti, besmrtnosti, pa i nepremostivosti između dvaju svjetova uz jasnu fascinaciju smrću. Međutim, dimenzija straha u Matoševoj kratkoj prozi nije realizirana u zazoru likova prema smrti, prema onostranom ili prema mogućoj realizaciji fantastičnih simbola, već, paradoksalno, u zazoru od realnoga svijeta.

Primjerice, ljubavnici novele Camao Alfred Kamenski i Fanny iracionalnim su tehnikama konstruirali idealizirani fantastični svijet apsolutne ljepote i vječne ljubavi, a strah se realizira tek $u$ onim epizodama kada je moguć povratak $u$ realistički intoniran svijet. Vrhunac napetosti, pa i nepremostivosti između fantastičnoga i realnoga svijeta ostvaren je u epizodi u kojoj se Fannyin muž Frost na sluginu dojavu o aferi vratio kući. U tom smislu, njegov završni koljački pohod i popratni simbol smrti ne predstavljaju klasični prijelaz u nepoznato i nespoznatljivo, nego smrt zapravo simbolizira siloviti povratak realnosti, nasilno raspršivanje romantičnoga zanosa te potpuno dokidanje imaginativnih odnosa koji su do te točke dominirali pripovjednom strukturom Camaa. Isti je mehanizam prepoznatljiv i u Mišu ili u noveli U čudnim gostima.

Realizacija straha u Matoševim novelama inovativna je i neobična te prati obrnuti smjer od Jorgovanića i Gjalskoga - umjesto straha od nepoznatoga fantastičnog svijeta nastupa strah od povratka iz eskapističke fantastike u empirijsku zbilju. Budući da Matoševa fantastika izvire iz nutrine opisanih karaktera, tj. iz psihopatologije sâmih likova, a osjećaj straha sveden je na razinu stalno prisutne tjeskobe, $u$ komparativnom pristupu model Maupassantove novelistike u kontekstu Matoševe dezintegracije realističke matrice pokazuje se relevantnijim za eventualnu komparativnu analizu (Sindičić Sabljo 2016: 102-103). 
Strah od vlastite fantazije koji postupno prerasta u kozmičke razmjere glavni je motivacijski motor Leskovarove inicijacije modernizma u noveli Misao na vječnost. Đuro Martić, glavni protagonist te novele, slično kao u Matoševu Mišu, odgovoran je za samoubojstvo svoje nekadašnje djevojke. Osebujno izvrtanje tipičnog poeovskog motiva mrtve drage sastoji se $u$ tome što je Martić žrtva vlastite psihološko-fantastične inscenacije u kojoj njegov teret prošlosti i nekadašnjih grijeha po astronomskim principima biva otisnut poput svjetlosti zvijezda i kao takva fiktivna materija putuje kroz Svemir. lako je mrtva draga motivski okidač koji vodi do znamenite posljednje rečenice "Đuro je Martić poludio", ona nije relativno kontrolirano okno $u$ fantastični svijet kao Jorgovanićev odar, nego se u prilično agorafobičnoj atmosferi eksponencijalno raspršuje u svim smjerovima. Zbog toga u slučaju Misli na vječnost možemo govoriti o jednom od rijetkih, ali zato kardinalnih primjera kozmičke strave u klasičnoj hrvatskoj književnosti. Motiv kozmičke strave također je tipični poeovski fantastični topos (npr. u novelama Rukopis pronađen u boci, Maska crvene smrti, Bunar i klatno) u kojem se protagonist nalazi na udaru sila čiji razmjeri značajno nadilaze (ne)mogućnost ljudskog razuma da shvati misterije Svemira. lako te sile mogu imati i ovozemaljsko obličje, ono je toliko pojačano da njihovo značenje postaje simboličko, a implikacije metafizičke. ${ }^{12} U$ Leskovarovu slučaju Martićeva analitika prošlosti postupno izrasta u kozmogonijsku srodnost s drugim bićima, ${ }^{13}$ a sudbonosna predestinacija događaja iz prošlosti progoni ga u sadašnjosti te sprečava i uništava njegovu budućnost. Drugim riječima, kozmička strava psihološki paralizira protagonista. U dostupnoj literaturi nije nađena interpretacija Leskovarova opusa u poeovskom ključu, čak ni usputna indicija ili potvrda o tome je li Leskovar čitao Poea. Međutim, prisutnost više poeovskih motiva u Misli na vječnost navodi na zaključak da je autor bio upoznat s tim okvirima, neposredno ili posredno.

\section{ZAKLJUČAK}

Interpretativni fokus ove kratke književnopovijesne analize odabranog korpusa klasičnih hrvatskih fantastičnih prozaika 19. stoljeća bio je posebno usmjeren na konkretizaciju emocije straha u njihovim djelima. Paradigma reprezentacija straha ukazuje prvenstveno na komparatistički aspekt i snažan utjecaj Poeove novelistike na hrvatske autore. Također, primjetna je evolucija ne samo pripovjednih strategija nego i, posljedično, različitih načina manifestacije osjećaja straha $u$ hrvatskom fantastičnom kanonu 19. stoljeća. U Jorgovanićevoj prozi strah je posredovan kombinacijom tipičnih romantičarskih motiva mrtve drage, neobičnih i bizarnih ambijenata i situacija te emocionalno-psiholoških doživljaja sâmih protagonista. Gjalskijev pripovjedni misticizam u jednadžbu unosi i snažan realistički impuls čime je težište geneze straha prebačeno na napetost između romantičarske

\footnotetext{
${ }^{12}$ Usp. Ognjanović (2014: 193-194).

${ }^{13}$ Usp. Milanja (1987: 20-21).
} 
zanesenosti i empirijske strogoće, tj. na upadanje fantastičnog u realni svijet i remećenje njegovih konvencionalnih zakonitosti. U skladu s modernističkom paradigmom, donekle i ironizacijom dotadašnjih postupaka koji su prepoznatljivi u fantastičarskom eskapizmu, emocionalno-psihološki doživljaji protagonista u Matoševoj novelistici radikalno mijenjaju svoj smjer: strah se ne generira u kontaktu s nepoznatim, onostranim, oniričkim, nego u mogućnosti ponovnog suočavanja sa zbiljom. Također, suprotno dotadašnjoj literarnoj praksi, učinak straha u Matoša nije usmjerena pripovjedna strategija, nego usputni, posljedični nusprodukt opće modernističke težnje prema psihopatološkim stanjima. U Leskovarovoj pak prozi to psihopatološko stanje, uz pojavljivanje klasičnih romantičarsko-fantastičnih motiva, gradativno prerasta u sudbonosnu obuzetost prošlošću i sveopću kozmičku stravu.

Manifestacije motiva straha razmjerno su slabo istražen fenomen u hrvatskoj znanosti o književnosti. S obzirom na uvodna razmatranja o fantastičnoj književnosti, kojoj je strah gradbeni element žanra, teško je jednoznačno odgovoriti na otvorena pitanja postavljena na početku teksta. Temeljno pitanje na koje je teško pronaći odgovor je: kojoj pripovjednoj razini strah zapravo pripada? Jer inicijaciju i realizaciju straha treba tražiti u sukobu između poznatog i nepoznatog, i to ne samo u tekstu, između protagonista i zastrašujućeg, nego osobito između čitatelja i zastrašujućeg. Jer, Nietzscheovim riječima, ako se dovoljno dugo zagledaš u bezdan, i bezdan se zagleda u tebe.

\section{NAVEDENA LITERATURA I IZVORI}

Barac, Antun. 1952. Hrvatska novela do Šenoine smrti. Zagreb: Jugoslavenska akademija znanosti i umjetnosti.

Bobinac, Marijan. 2012. Uvod u romantizam. Zagreb: Leykam international.

Carrol, Noël. 2004. The Philosophy of Horror or Paradoxes of the Heart. New York, London: Routledge. https://doi.org/10.4324/9780203361894

Detoni-Dujmić, Dunja. 1982. “Imaginarne i fantazijske strukture na relaciji Poe-Gjalski-Matoš”. Književna smotra 14/47-48: 80-88.

Donat, Branimir. 1975. "Stotinu godina fantastičnoga u hrvatskoj prozi". U Antologija hrvatske fantastične proze i slikarstva. Branimir Donat i lgor Zidić, ur. Zagreb: Sveučilišna naklada Liber, 7-56.

Donat, Branimir i lgor Zidić, ur. 1975. Antologija hrvatske fantastične proze i slikarstva. Zagreb: Sveučilišna naklada Liber.

Gjalski, Ksaver Šandor. 1913. Tajinstvene priče. Zagreb: Naklada piščeva.

Grgić, Kristina. 2016. “Motiv mrtve ljubavi u Jorgovanićevoj i Gjalskijevoj fantastičnoj prozi”. U Komparativna povijest hrvatske književnosti - Zbornik radova XVIII - Fantastika: problem zbilje. Cvijeta Pavlović, Vinka Glunčić-Bužančić i Andrea Meyer-Fraatz, ur. Split, Zagreb: Književni krug Split, Odsjek za komparativnu književnost Filozofskoga fakulteta Sveučilišta u Zagrebu, 58-76.

Katušić, Bernarda. 2017. Književno njihalo. Tri pisma novije hrvatske književnosti: autobiografsko, bajkovno i medijalno. Zagreb: Meandarmedia.

Kuvač-Levačić, Kornelija. 2013. Moć i nemoć fantastike. Split: Književni krug Split. 
Lőkös, István. 2010. “Misticizam, simbolizam ili simbolistički pokušaji”. U Pristupi Gjalskom. Zagreb: Matica hrvatska, 286-334.

Marković, Franjo, Lavoslav Vukelić, Andrija Palmović i Rikard Jorgovanić. 1970. Izabrana djela. Pet stoljeća hrvatske književnosti, 44. Zagreb: Zora, Matica hrvatska.

Matoš, Antun Gustav. 1967. Pjesme - Pripovijesti - Autobiografija. Pet stoljeća hrvatske književnosti, 64. Zagreb: Zora, Matica hrvatska.

Mendlesohn, Farah. 2008. Rhetorics of Fantasy. Middletown, Connecticut: Wesleyan University Press.

Mendlesohn, Farah i Edward James. 2012. A Short History of Fantasy. Oxfordshire: Libri Publishing.

Milanja, Cvjetko. 1987. Janko Leskovar. Zagreb: Zavod za znanost o književnosti Filozofskog fakulteta Sveučilišta u Zagrebu, Sveučilišna naklada Liber.

Moorcock, Michael. 2004. Wizadry and Wild Romance. A Study of Epic Fantasy. Austin: Monkeybrain.

Nemec, Krešimir. 1994. "Hrvatska fantastična proza”. U Večernji akt Pavla Pavličića - Mor Đure Sudete - Pripovijesti Dinka Šimunovića (Mrkodol, Muljika, Alkar). Krešimir Nemec i Dunja Detoni-Dujmić. Zagreb: Školska knjiga.

Ognjanović, Dejan. 2014. Poetika horora. Novi Sad: Orfelin izdavaštvo.

Oraić Tolić, Dubravka. 2013. Čitanja Matoša. Zagreb: Naklada Ljevak.

Pavičić, Jurica. 1996. “Neka pitanja teorije fantastične književnosti”. Mogućnosti 43/4-6: 133-147.

Peričić, Helena. 1999. "Neke književnokomparatističke asocijacije nad djelom R. Jorgovanića”. U Dani hvarskog kazališta XXV. Hrvatska književnost od preporoda do Šenoina doba. Nikola Batušić, Rafo Bogišić, Rudolf Filipović, Milan Moguš, Franjo Švelec i Josip Vončina, ur. Split: Književni krug Split, 319-336.

Pogačnik, Jagna. 2000. “Fantastična proza Ksavera Šandora Gjalskog”. U Dani hvarskog kazališta. Razdoblje realizma u hrvatskoj književnosti i kazalištu. Nikola Batušić, Rafo Bogišić, Rudolf Filipović, Milan Moguš, Franjo Švelec i Josip Vončina, ur. Zagreb, Split: Hrvatska akademija znanosti i umjetnosti, Književni krug Split, 84-96.

Pogačnik, Jagna. 1999. "Fantastična proza Rikarda Jorgovanića”. U Dani hvarskog kazališta XXV. Hrvatska književnost od preporoda do Šenoina doba. Nikola Batušić, Rafo Bogišić, Rudolf Filipović, Milan Moguš, Franjo Švelec i Josip Vončina, ur. Split: Književni krug Split, 337-350.

Sindičić Sabljo, Mirna. 2016. “Matoš i Maupassantov model fantastične novele”. U Komparativna povijest hrvatske književnosti. Zbornik radova XVIII - Fantastika: problem zbilje. Cvijeta Pavlović, Vinka Glunčić-Bužančić i Andrea Meyer-Fraatz, ur. Split, Zagreb: Književni krug Split, Odsjek za komparativnu književnost Filozofskoga fakulteta Sveučilišta u Zagrebu, 95-108.

Stojanović, Bojana. 1983. “Đalski i Edgar Alan Po (srodnosti i razlike)". Književna historija 16/61: 439452.

Šicel, Miroslav. 1991. Rikard Jorgovanić. Zagreb: Zavod za znanost o književnosti Filozofskog fakulteta.

Todorov, Cvetan. 1987. Uvod u fantastičnu književnost. Beograd: Rad, Kozmos.

Wellek, René i Austin Warren. 1949. Theory of Literature. New York: Harcourt, Brace and Company. 


\section{THE MOTIF OF FEAR AND ITS MECHANISMS IN THE CROATIAN FANTASTIC NOVEL OF THE 19TH CENTURY}

Given that from Romanticism onward the fantastic in world narrative fiction centers around the idea of fear of the unknown and inexplicable, this paper explores the manifestations of this emotion in selected Croatian fantastic stories from the 19th century. Since the concept of genre is a variable category dependent on a number of literary and non-literary factors, this paper also discusses topic and genre qualification, especially considering the presence of motifs related to the emotion of fear. In the Western literature of the 19th century, the fantastic narrative genre with the motive of fear as the main narrative core is quite frequent. Some elements of fantastically intoned literature with features of literary horror are also present in the research corpus: from the romantic features of Jorgovanić's fantasy, the bridging of realistic poetics and the turn to mysticism in Gjalski's stories to the modernist psychologization of Matoš and Leskovar. Although traditional Croatian literary historiography does not interpret its basic corpus through the prism of the motif of fear, its presence leads to a number of research questions: how does fear manifest itself in the narrative text?, which narrative level does the emotion of fear belong to?, how does the motif of fear participate in the production of the fantastic and irreal? etc.

Keywords: fantastic, horror, mysticism, novel, fear, intrusive fantasy 